\title{
The Assessment and Mentoring Program (AMP): Final year pre-service physical education peer mentors' perceptions of effective mentoring
}

\author{
Kate A Jenkinson and Amanda C Bensonı
}

\begin{abstract}
In the teacher education context, most peer mentoring programs have focused on pre-service teachers and a qualified teacher mentor within schools (Hobson, et.al., 2009; Ambrosetti, Knight \& Dekkers, 2014). Few studies have focused on mentoring between pre-service physical education teachers. Therefore, we describe the Assessment and Mentoring Program (AMP): a four-way collaborative learning community. Mentoring occurs between final year physical education students (mentors), reciprocally between mentors and their year two mentees, and in collaboration with lecturers. Prior to the commencement of the AMP, to understand the preservice mentors' perception of effective mentoring, they were asked to annotate an $A 3$ poster with the characteristics they perceived were required to be the 'perfect' mentor and complete the AMP successfully. We present data of their perceptions. De-identified data were transcribed verbatim, coded and analyzed using NVivo (Version10) software to explore themes of the mentor's perceptions of effective mentoring within the context of Le Cornu's (2005) critical mentoring framework including interpersonal skills, a mentoring attitude and critical reflection. The AMP mentors identified characteristics in all three categories; organization was also identified as an essential mentoring characteristic. Students' perceived a diverse set of mentoring skills were required. Given that many key skills developed through mentoring are important for pre-service teachers when they graduate, the challenge is how to provide relevant, authentic and context specific experiences for students that enable them to become collaborative reflective practitioners who can provide quality learning and assessment opportunities for their own diverse students within the constraints of a university environment.
\end{abstract}

Keywords: assessment, mentoring, physical education, pre-service teachers, effective mentoring

1 RMIT University, School of Health and Biomedical Science, Bundoora VIC, 3083, Australia. kate.jenkinson@rmit.edu.au; amanda.benson@rmit.edu.au 
Diverse student populations in universities have prompted the development of mentoring programs aimed at supporting first year students to successfully perform academically and to reduce attrition rates (Heirdsfield, Walker, Walsh, \& Wilss, 2008). Many universities are attempting to foster a sense of engagement through such programs (Egege \& Kutieleh, 2015). This support is usually received only during this first year transition period and students may be provided with any number of different mentoring approaches including: discipline specific programs, peer mentoring and tutoring or online support and academic support programs (Ashwin, 2002; Heirdsfield et al., 2008; Krause, Hartley, James, \& McInnis, 2005; O’Regan, Geddes, Howe-Piening, \& Quirke, 2004; Rittschof \& Griffin, 2001). Following this year of transition, students are left to navigate the remainder of their degree and expected to become independent, self-regulated learners (ten Cate, Snell, Mann, \& Vermunt, 2004).

The continually contested operational definition of 'mentoring', the assumed rather than demonstrated success of mentoring, the lack of rigor in this research area and broad contexts that mentoring occur in (Crisp \& Cruz, 2009; Egege \& Kutieleh, 2015; Jacobi, 1991) make it difficult to decipher and compare findings. Despite this, some reported outcomes of mentoring in undergraduate programs have included for the mentor or mentee: increased satisfaction, fulfillment, productivity, work-related benefits, recognition from others, respect, emotional support, behavior and classroom management skills, interpersonal skills, critical reflection and leadership capacity (Crisp \& Cruz, 2009; Eby, Durley, Evans, \& Ragins, 2006; Ehrich, Hansford, \& Tennent, 2004; Hobson, Ashby, Malderez, \& Tomlinson, 2009).

Within teacher education, peer mentoring programs have often focused on the relationship between the pre-service teacher and the mentor who is a qualified teacher within a school setting (Hobson et al., 2009). In contrast to the experienced teacher providing feedback, Le Cornu (2005) described the use of peer mentoring between students during their final teaching practicum experience. This peer mentoring process which involved a collaborative peer partnership, where neither held a position of power over the other, enabled three critical mentoring skills to be developed which Le Cornu (2005) highlights are crucial components in a pre-service teacher education mentoring program. These critical mentoring skills requiring development include: a mentoring attitude which values the learning of both parties, interpersonal skills to communicate across multiple stakeholders and critical reflection skills to challenge ideas and beliefs (Le Cornu, 2005).

The above examples of mentoring models which exist between the same year level students' or between first and final year students are quite commonly found across universities in Victoria, Australia. Examples of mentoring programs specifically in teacher education are few (Heirdsfield et al., 2008) and there are even fewer studies focusing on peer mentoring between students within physical education pre-service courses. One such study reported on the Student Teaching Experience in Mentoring (STEM) program focusing on outcomes for final year physical education mentors who acted as peer mentors to first year students (Mooney \& Gullock, 2013). Outcomes such as the development of a mentoring attitude and critical reflection were reported in the Assessment for Learning tasks completed. To our knowledge, studies of mentoring between other year levels, other than first and final year students, within physical education pre-service teaching courses have not been investigated. Therefore, this study investigates the effective mentoring characteristics perceived to be required in a pre-service physical education teaching context between final year ( $4^{\text {th }}$ year students) mentors and second year mentees where the intention

Journal of the Scholarship of Teaching and Learning, Vol. 17, No. 2, April 2017. josotl.indiana.edu 
is not about 'surviving' the transition to University and teaching practice, but rather the development of teaching, planning for teaching, assessment and mentoring skills which are work ready skills that are transferable to future teaching environments.

\section{The Assessment and Mentoring Program (AMP)}

Collaboration with students is a goal for the Scholarship of Teaching and Learning (SoTL) and it has the potential to transform teaching and learning in higher education (Allin, 2014). In an attempt to provide authentic learning opportunities and develop work ready attributes through collaboration, the Assessment and Mentoring Program (AMP), a four-way collaborative learning community underpinned by social constructivism (Bruner, 1996) was developed. The AMP was designed to provide opportunities for final year mentors to offer feedback on their second year mentee's teaching experiences and for discourse between mentors. The four-way collaboration is operationalised with mentoring occurring between final year physical education students as mentors, reciprocally between mentors and their second year mentees, and in collaboration with their lecturers. Furthermore, mentors develop, test, implement and moderate a lesson plan assessment tool. This scaffolded process of assessment design, implementation, and critical reflection is a unique attribute of the AMP that enables mentors to work collaboratively with each other and their lecturers to develop these skills in a supportive environment.

\section{Method}

\section{Participants}

All final year (Year 4) pre-service physical education students $(n=102)$ during the 2014 and 2015 academic years were invited to apply to participate in the AMP study. The study only required between 8-10 mentors each year as the maximum ratio required was one final year mentor to work with 6-8 Year 2 mentees from a mentee cohort of between 55-65 students each year. University Human Ethics approval was granted and informed consent obtained from a total of 17 applicants aged $19-23$ years $(\mathrm{M}=10 ; \mathrm{F}=7)$. It was not required that mentors had to participate in data collection to be part of the AMP. The mentors met in February of each year prior to the commencement of the academic year to begin the AMP preparations. Prior to the commencement of the AMP the requirements of the program were outlined and students were asked to reflect on mentoring and the attributes of effective mentors. The mentors were then asked to annotate an A3 poster of a figure with the characteristics they perceived to be the 'perfect' mentor that could complete the demands of the AMP successfully.

\section{Data Analysis}

De-identified data were transcribed verbatim, coded and analyzed using NVivo (Version10) software. Immersion and familiarization of data (Grbich, 2013) was followed by the exploration of themes within the context of Le Cornu's (2005) three critical mentoring components. Using the three constructs (attitude, interpersonal skills, critical reflection skills), this provided a framework for a code book (DeCuir-Gunby, Marshall, \& McCulloch, 2011) with inclusion and exclusion criteria and examples from the data to 
Jenkinson and Benson

ensure accuracy. A word frequency query was performed to gain insight into the key themes; this enabled sub-categories to be identified under each theme, with one key theme additional to Le Cornu's (2005) framework identified.

\section{Findings}

The 17AMP mentors reported diverse characteristics were going to be required to successfully complete their mentoring roles. Examples of annotated posters from the mentors can be seen in Figure 1.

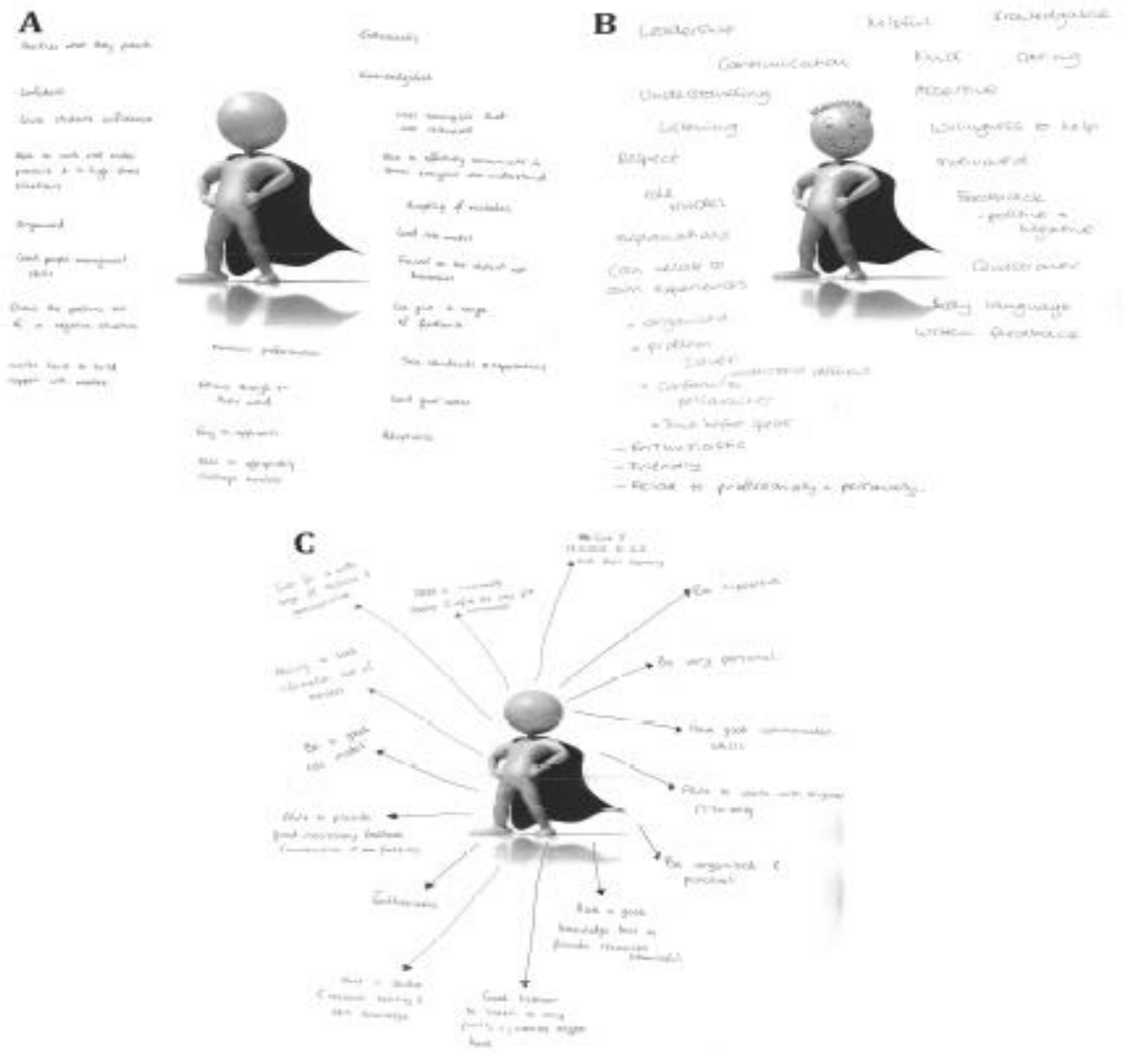

Figure 1: An example of an AMP students annotated poster of their perception of important characteristics of the 'perfect' mentor prior to the commencement of the AMP program

Journal of the Scholarship of Teaching and Learning, Vol. 17, No. 2, April 2017. 
The AMP mentors identified characteristics in all three categories that Le Cornu (2005) described as important attributes to develop for successful peer mentoring in preservice teacher education and an additional theme was also identified (Table 1).

\section{Table 1: Attributes identified by final year pre-service physical education peer mentors as important for successful mentoring prior to the commencement of the AMP}

\begin{tabular}{|c|c|c|}
\hline $\begin{array}{l}\text { Requirements of } \\
\text { mentoring in pre-service } \\
\text { teacher education courses }\end{array}$ & Sub-categories $^{2}$ & $\begin{array}{l}\text { Examples of perceived requirements of a 'perfect' } \\
\text { mentor }\end{array}$ \\
\hline Mentoring attitude $^{1}$ & $\begin{array}{l}\text { Attitude and effort } \\
\text { Content knowledge } \\
\text { Leader/Role model } \\
\text { Valuing others and own } \\
\text { learning }\end{array}$ & $\begin{array}{l}\text { "having a positive attitude" } \\
\text { "applying effort" } \\
\text { "being motivating and passionate" } \\
\text { "engaged" } \\
\text { "practice what you preach" } \\
\text { "knowing more than them, being knowledgeable" } \\
\text { "being a leader, approachable, role model, solid and build } \\
\text { respect" } \\
\text { "develop a partnership" } \\
\text { "share information" } \\
\text { "focus is on the mentee not the mentor" }\end{array}$ \\
\hline Interpersonal skills $^{1}$ & $\begin{array}{l}\text { Communication skills } \\
\text { To develop relationships }\end{array}$ & $\begin{array}{l}\text { "deal with conflict, display empathy, be understanding and } \\
\text { patient, listen and be assertive" } \\
\text { "effectively communicate so everyone can understand" } \\
\text { "develop trust" } \\
\text { "bring personal experiences to share" } \\
\text { "persistent" } \\
\text { "consistent" } \\
\text { "productive" } \\
\text { "flexible, adaptable" } \\
\text { "approachable" } \\
\text { "open minded" } \\
\text { "relatable" } \\
\text { "ability to create unity" } \\
\text { "acceptable of mistakes" } \\
\text { "work hard to build a rapport" } \\
\text { "helpful, kind, supportive" } \\
\text { "gives mentees confidence" } \\
\text { "responsible/respectable" } \\
\text { "relaxed but not too relaxed" } \\
\text { "stoic" } \\
\text { "enthusiastic" } \\
\text { "friendly" } \\
\text { "good body language" }\end{array}$ \\
\hline Critical reflection $^{1}$ & Professional behavior & $\begin{array}{l}\text { "being involved in professional dialogue" } \\
\text { "strong ethics/morals" } \\
\text { "use relevant examples" } \\
\text { "sets standards and expectations, set appropriate goals" } \\
\text { "think before speaking" } \\
\text { "cater for a wide range of abilities and personalities" }\end{array}$ \\
\hline
\end{tabular}

Journal of the Scholarship of Teaching and Learning, Vol. 17, No. 2, April 2017. 


\begin{tabular}{|c|c|c|}
\hline & Feedback & $\begin{array}{l}\text { "taking feedback from mentees" } \\
\text { "critiquing others and giving feedback" } \\
\text { "giving quality feedback" (written and verbal) } \\
\text { "providing feedback in different ways to meet student } \\
\text { needs" }\end{array}$ \\
\hline Organization & $\begin{array}{l}\text { Being challenged and } \\
\text { challenging mentees }\end{array}$ & $\begin{array}{l}\text { "challenging own ideas and beliefs" } \\
\text { "justify yourself " } \\
\text { "draw positives out of negative situations" } \\
\text { "follow through" } \\
\text { "challenge mentee" } \\
\text { "get mentee to use initiative" } \\
\text { "solve problems" } \\
\text { "draw information from mentee" } \\
\text { "prepared" } \\
\text { "time management skills" } \\
\text { "available" } \\
\text { "reliable" } \\
\text { "reachable" } \\
\text { "punctual" } \\
\text { "work well under pressure and in high stress situations" }\end{array}$ \\
\hline
\end{tabular}

${ }^{1}$ Previously identified by Le Cornu, 2005 as important attributes of mentoring in pre-service teacher education programs; ${ }^{2}$ Note all subcategories were developed in our attempt to further explain Le Cornu's (2005) framework.

\section{Discussion}

Understanding the key skills required is necessary before embarking on mentoring in any context (Heirdsfield et al., 2008). This recognition of skills is important as it provides mentors the chance to reflect through a 'mentoring lens' and assess their own ability to mentor others and consider the commitment ahead. Whilst Le Cornu's (2005) mentoring framework was previously applied to peer-to-peer mentoring when completing a classroom-based teaching placement in a school, the different context of the AMP resulted in some notable differences in the perceived mentoring attributes. The AMP provides mentoring that occurs across different year levels (final year to second year), it includes the assessment of lesson planning and there was no actual observation of their mentees teaching every week. The context specific attribute that final year physical education students additionally identified as important for a 'perfect' mentor to possess was organization.

Le Cornu (2005) describes the mentoring attitude as valuing "both one's own and the learning of others" (pg. 359). The AMP mentors perceived that they would need to share and value their mentee's insights and would need to be a positive role model whilst motivating others, being passionate and engaging. Mentors also perceived an opportunity to demonstrate leadership skills. These findings are partially in support but also in contrast to the Le Cornu's (2005) framework where leadership and role modelling are not identified as important mentoring attributes due perhaps to the peer mentoring relationship in that study having the same hierarchical status where students were both in the final year of their degree. However, Crisp and Cruz's (2009) critical review of mentoring outlines role 
modelling occurs within many higher education mentoring programs involving 'experienced' and 'lesser-experienced' participants. If AMP mentors perceived they were going to be a role model, it was not surprising that "knowing more than them" was considered an important attribute to possess and exemplifies the mentoring attitude of "valuing one's own learning". Studies specifically on mentoring in pre-service teacher education which have focused on the hierarchical mentoring relationships in different contexts have discussed the importance of mentors being able to perform roles such as: supporter, role model, and facilitator amongst others (Ambrosetti \& Dekkers, 2010; Ambrosetti, Knight, \& Dekkers, 2014).

Interpersonal skills or characteristics of effective mentors in mentoring programs have included: honesty, empathy, empowering, trustworthiness, active listing, being altruistic, engaged, experienced and accessible (Crisp \& Cruz, 2009; Straus, Johnson, Marquez, \& Feldman, 2013). Terrion and Leonard (2007) found for stable relationships to develop, mentors must be perceived as trustworthy. To achieve this trusting relationship, key attributes to generate trust are vital. The AMP mentors identified the following skills required they perceived were to be important in their future roles to communicate and develop relationships: empathy, understanding, speaking and listening, assertively communicating and provide reciprocal learning opportunities by sharing of experiences. The awareness by the AMP mentors of their entire responsibility, including assessment of their mentees lesson plans, was evident with the identification of the need for consistency during assessment. Previously described by Ambrosetti and Dekkers (2010), the role of the 'assessor' involves the mentor assigning a grade or marks criteria. This aspect of the AMP role is undertaken weekly by the AMP mentors when analysing lesson plan content and providing feedback on areas for improvement.

In schools, the mentoring of others promotes the greatest amount of learning through self-reflection or critical reflection of their own practices (Hobson et al., 2009).Within this mentoring program in an undergraduate degree, the AMP mentors recognised the importance of feedback in this reflective process. In particular, drawing attention to the need of a 'perfect' mentor to be receptive to feedback from their mentees and the mentor's abilities to critique others work and provide appropriate, high quality feedback. Importantly, some also perceived that feedback should be provided in different ways to meet different mentees needs as all students learn and respond to feedback differently. This feedback process is something the AMP mentors have been participants in throughout their own teaching placement experiences (from school supervisors, university supervisors and peers of their own year level). The mentors identified that it is imperative that 'perfect' mentors are well versed in justifying how they have assessed and critiqued their mentee's lesson plans during meeting times. However, they also recognised that the 'perfect' mentor needs to be open to mentees challenging their ideas and that they need to have the ability to engage in professional dialogue.

Not identified in Le Cornu's (2005) framework, organization was considered a key attribute for a 'perfect' mentor to possess to undertake the AMP effectively. Ehrich, Hansford and Tennet (2004) report that the most commonly cited difficulty in mentoring in education was the lack of time, thus supporting the perceived need by AMP mentors to develop time management skills to balance their own study and role in the mentoring program. Difficulties contacting mentees was also discussed by Enrich et al., (2004) as a limiting factor in mentoring success and is supported in this study as AMP mentors

Journal of the Scholarship of Teaching and Learning, Vol. 17, No. 2, April 2017. josotl.indiana.edu 
identified that they (as the 'perfect' mentor) would need to be available, reachable, punctual and contactable to complete their roles.

\section{Conclusions}

Crisp and Cruz (2009) suggest there are up to 50 identifiable functions associated with the mentoring role. By using Le Cornu's (2005) mentoring framework relevant to pre-service teacher education we have found that the AMP mentors have identified the requisite skills required to be a 'perfect' mentor and opportunities can then be provided for them to develop such skills through training and participation in the AMP. We have also identified an additional skill, organization, required when physical education pre-service teachers mentor each other, across different year levels, in a combined academic and teaching context. The attributes identified as important for the 'perfect' mentor are also those necessary to produce work ready graduates. Given that we know many key skills developed through mentoring are important for pre-service teachers when they graduate, the challenge is how to provide relevant, authentic and context specific experiences for students that enable them to become collaborative reflective practitioners who can provide quality learning and assessment opportunities for their own diverse students within the constraints of a university environment.

\section{References}

Allin, L. (2014). Collaboration between staff and students in the Scholarship of Teaching and Learning: The potential and the problems. Teaching and Learning Inquiry: The ISSOTL Journal, 2(1), 95-102. doi: 10.2979/teachlearninqu.2.1.95

Ambrosetti, A., \& Dekkers, J. (2010). The interconnectedness of the roles of mentors and mentees in pre-service teacher education mentoring relationships. Australian Journal of Teacher Education, 35(6). doi: 10.14221/ajte.2010v35n6.3

Ambrosetti, A., Knight, B. A., \& Dekkers, J. (2014). Maximizing the potential of mentoring: A framework for pre-service teacher education. Mentoring \& Tutoring: Partnership in Learning, 22(3), 224-239. doi: 10.1080/13611267.2014.926662

Ashwin, P. (2002). Implementing Peer Learning Across Organisations: the development of a model. Mentoring and Tutoring, 10(3), 221-231. doi: 10.1080/1361126022000037051

Bruner, J. S. (1996). The culture of education. Cambridge, MA: Harvard University Press.

Crisp, G., \& Cruz, I. (2009). Mentoring college students: A critical review of the literature between 1990 and 2007. Research in Higher Education, 50(6), 525-545. doi: 10.1007/s11162-009-9130-2

DeCuir-Gunby, J. T., Marshall, P. L., \& McCulloch, A. W. (2011). Developing and using a codebook for the analysis of interview data: an example from a professional development research project. Field Methods, 23(2), 136-155. doi: 10.1177/1525822X10388468

Eby, L. T., Durley, J. R., Evans, S. C., \& Ragins, B. R. (2006). The relationship between short-term mentoring benefits and long-term mentor outcomes. Journal of Vocational Behavior, 69(3), 424444. doi: 10.1016/j.jvb.2006.05.003

Journal of the Scholarship of Teaching and Learning, Vol. 17, No. 2, April 2017. josotl.indiana.edu 
Jenkinson and Benson

Egege, S., \& Kutieleh, S. (2015). Peer mentors as a transition strategy at University: Why mentoring needs to have boundaries. Australian Journal of Education, 59(3), 265-277. doi:

$10.1177 / 0004944115604697$

Ehrich, L. C., Hansford, B., \& Tennent, L. (2004). Formal mentoring programs in education and other professions: A review of the literature. Educational administration quarterly, 40(4), 518-540. doi: $10.1177 / 0013161 X 04267118$

Grbich, C. (2013). Foreword: Depth psychological research methods. International Journal of Multiple Research Approaches, 7(3), 286-286. doi: 10.5172/mra.2013.7.3.286

Heirdsfield, A. M., Walker, S., Walsh, K., \& Wilss, L. (2008). Peer mentoring for first-year teacher education students: The mentors' experience. Mentoring \& Tutoring: Partnership in Learning, 16(2), 109-124. doi: 10.1080/13611260801916135

Hobson, A. J., Ashby, P., Malderez, A., \& Tomlinson, P. D. (2009). Mentoring beginning teachers: What we know and what we don't. Teaching and teacher education, 25(1), 207-216. doi:

10.1016/j.tate.2008.09.001

Jacobi, M. (1991). Mentoring and undergraduate academic success: A literature review. Review of educational research, 61(4), 505-532. doi: 10.3102/00346543061004505

Krause, K.-L., Hartley, R., James, R., \& McInnis, C. (2005). The first year experience in Australian universities: Findings from a decade of national studies. Melbourne: Centre for the Study of Higher Education, University of Melbourne

Le Cornu, R. (2005). Peer mentoring: engaging pre-service teachers in mentoring one another. Mentoring \& Tutoring: Partnership in Learning, 13(3), 355-366. doi:

$10.1080 / 13611260500105592$

Mooney, A., \& Gullock, L. (2013). "Back to the Future" Building Mentoring Capacity in Physical Education Teacher Education Students. In R. Brandenburg \& J. Z. Wilson (Eds.), Pedagogies for the Future (pp. 85-98). Rotterdam Boston: Springer.

O’Regan, K., Geddes, J., Howe-Piening, S., \& Quirke, S. (2004). Starting@ University: A transition web-site developed by students. Paper presented at the 8th Pacific Rim-First Year Experience in Higher Education Conference. July. Brisbane,, Australia: Queensland University of Technology \& Monash University.

Rittschof, K. A., \& Griffin, B. W. (2001). Reciprocal peer tutoring: Re-examining the value of a co-operative learning technique to college students and instructors. Educational Psychology, 21(3), 313-331. doi: 10.1080/01443410123903

Straus, S. E., Johnson, M. O., Marquez, C., \& Feldman, M. D. (2013). Characteristics of successful and failed mentoring relationships: a qualitative study across two academic health centers.

Academic medicine: journal of the Association of American Medical Colleges, 88(1), 82-89. doi: 10.1097/ACM.0b013e31827647a0

ten Cate, O., Snell, L., Mann, K., \& Vermunt, J. (2004). Orienting teaching toward the learning process. Academic Medicine, 79(3), 219-228.

Journal of the Scholarship of Teaching and Learning, Vol. 17, No. 2, April 2017. josotl.indiana.edu 
Jenkinson and Benson

Terrion, J. L., \& Leonard, D. (2007). A taxonomy of the characteristics of student peer mentors in higher education: findings from a literature review. Mentoring \& Tutoring: Partnership in Learning, 15(2), 149-164. doi: 10.1080/13611260601086311

Journal of the Scholarship of Teaching and Learning, Vol. 17, No. 2, April 2017. josotl.indiana.edu 